\title{
Oxidation during magma mixing recorded by symplectites at Kusatsu-Shirane Volcano, Central Japan
}

\author{
Kenta Ueki ${ }^{*} \mathbb{D}$, Mutsuko Inui ${ }^{2}$, Kenta Matsunaga ${ }^{2}$, Naoya Okamoto ${ }^{2}$ and Kazuki Oshio ${ }^{2}$
}

\begin{abstract}
Kusatsu-Shirane Volcano is an active Quaternary andesitic-to-dacitic volcano located in the Central Japan Arc. We conducted a detailed petrological investigation of orthopyroxene (opx)-magnetite ( $\mathrm{mt}$ ) symplectites associated with olivine in the Sessho lava, an andesitic lava flow from Kusatsu-Shirane. We concluded that the symplectites are pseudomorphs after olivine and were formed through the breakdown of olivine in a mafic magma as a result of oxidation during mixing with a felsic magma. Various olivines and opx-mt symplectites that show different stages of the progressive breakdown reaction of olivine coexist in a single lava flow. We suggest that basaltic recharge into the magma reservoir beneath Kusatsu-Shirane occurred repeatedly, leading to a hybrid andesite magma with different types of olivine and symplectite being erupted at Kusatsu-Shirane Volcano.
\end{abstract}

Keywords: Kusatsu-Shirane, Andesite, Symplectite, Magma mixing, Olivine, Active volcano

\section{Introduction}

Mixing between mafic and felsic magmas in arc crust is considered to be an essential process not only for generating various arc magmas (Anderson 1976; Koyaguchi 1986; Sakuyama 1979; Ueki and Iwamori 2017), but also for the chemical evolution of a continental arc (Arndt 2013; Hildreth and Moorbath 1988; Tatsumi and Suzuki 2009). Understanding magma mixing could also be important for understanding the magmatic activity that leads to eruption, as mixing between mafic and felsic magma is a possible trigger for explosive magmatic eruptions (Sparks et al. 1977). Petrological investigations of the textures and zoning profiles of minerals provide information on such open-system magmatic processes (e.g., Streck 2008). In this study, we investigate magma mixing and the magma plumbing system of Kusatsu-Shirane Volcano, a Quaternary andesitic-to-dacitic active

\footnotetext{
*Correspondence: kenta_ueki@jamstec.go.jp

${ }^{1}$ Research Institute for Marine Geodynamics, Japan Agency for MarineEarth Science and Technology, 2-15 Natsushima-cho, Yokosuka,

Kanagawa 237-0061, Japan

Full list of author information is available at the end of the article
}

volcano located in the Central Japan Arc, using detailed petrological observations of orthopyroxene (opx)-magnetite $(\mathrm{mt})$ symplectites found in an andesitic lava flow.

Kusatsu-Shirane is a composite volcano that consists of multiple pyroclastic cones and craters, including Shirane, Moto-shirane, Kagamiike, and Kagamiike-kita (e.g., Hayakawa 1983; Hayakawa and Yui 1989; Takahashi et al. 2010; Uto et al. 1983). Kusatsu-Shirane is known for its hydrothermal system, with active hot springs and fumaroles (e.g., Ohba et al. 2008, 2019; Terada 2018). Geophysical studies including seismic (Kumagai et al. 2002; Nakano and Kumagai 2005; Nakano et al. 2003) and magnetotelluric methods (Matsunaga et al. 2020; Nurhasan et al. 2006) have been conducted to understand the structure of the hydrothermal system beneath KusatsuShirane. The hydrothermal heat flow rate around Kusatsu-Shirane is one of the highest for an active volcano in the Japan Arc (e.g., Sumi 1977; Ueki and Terada 2012). Historical eruptions of Kusatsu-Shirane have been dominated by phreatic eruptions from the Shirane pyroclastic cone (e.g., Ossaka et al. 1980), and on January 23, 2018, phreatic eruptions occurred at the Kagamiike-kita and Kagamiike pyroclastic cones (e.g., Terada et al. 2018). 
Although historical activity of Kusatsu-Shirane has been typified by hydrothermal activity and phreatic eruptions, voluminous andesitic-to-dacitic lava flows have also been erupted throughout its lifetime (Hayakawa and Yui 1989). In this study, we present petrological observations of opx-mt symplectites found in an andesitic lava flow from Kusatsu-Shirane. We use the process of formation of these symplectites to investigate the magma plumbing system of Kusatsu-Shirane Volcano, which has produced voluminous andesitic magma.

\section{Geological setting and sample descriptions}

Kusatsu-Shirane is located about $25 \mathrm{~km}$ in the back-arc direction from Asama Volcano, which is in the volcanic front of the Central Japan Arc (Fig. 1). The Pacific and Philippine plates are subducting beneath Kusatsu-Shirane. The surface of the Pacific Plate is about $150 \mathrm{~km}$ beneath the volcano (Nakajima and Hasegawa 2006). Although the Philippine Sea Plate is not clearly detected beneath Kusatsu-Shirane in seismic studies, its surface is estimated to be at a depth of $110 \mathrm{~km}$ based on extrapolation (Hirose et al. 2008; Nakajima et al. 2009). The seismic Moho beneath Kusatsu-Shirane is at a depth of $\sim 40 \mathrm{~km}$ (Zhao et al. 1992). Regions of high seismic attenuation are observed in the uppermost mantle beneath the volcano, and the central part of the high seismic attenuation zone (30-100 km depth) is interpreted to be a zone of partial melting (Kashiwagi and Nakajima 2019).

The basement at Kusatsu-Shirane is made up of altered Neogene volcanic rocks (Hayakawa and Yui 1989; Uto et al. 1983) and the Quaternary Yokote volcanic rocks (Kaneko et al. 1991). Following basalticandesitic activity at Matsuozawa Volcano at $\sim 0.6 \mathrm{Ma}$ (Kaneko et al. 1991; Nagai et al. 2015), volcanic activity at Kusatsu-Shirane started with the eruption of the Horakuchi lava flow and the dacitic Oshi pyroclastic flow at around 0.55 Ma (Kaneko et al. 1991; Nagai et al. 2015). A period of quiescence between $0.25 \mathrm{Ma}$ and $14 \mathrm{ka}$ interrupted volcanic activity that involved the eruption of voluminous lava flows including the Aoba (0.3 Ma), Heibei-ike ( $14 \mathrm{ka})$, Kagusa ( $7 \mathrm{ka})$, Sessho ( $\sim 3 \mathrm{ka})$, Ishizu ( $3 \mathrm{ka})$, and Furikozawa ( $3 \mathrm{ka})$ lavas, alongside associated pyroclastic cones and lava domes (e.g., the Moto-shirane and Shirane pyroclastic cones) and the Yazawahara pyroclastic flow (Hayakawa and Yui 1989; Kaneko et al. 1991; Takahashi et al. 2010; Uto et al. 1983). The $\mathrm{SiO}_{2}$ contents of the magmas erupted since $0.55 \mathrm{Ma}$ are restricted to 58-66 wt\% (Takahashi et al. 2010). Basaltic, amphibole-bearing (i.e., hydrous) melt inclusions have been reported in olivine phenocrysts in an andesite lava from Kusatsu-Shirane (Yamaguchi et al. 2005). Textures indicating mingling between andesite and dacite are found in some lavas
(Ushioda 2015; Uto et al. 1983). On Harker diagrams, many major-element oxides decrease toward a dacitic composition with $\mathrm{SiO}_{2}$ content of $\sim 65$ wt\%, and dacite with $\sim 65 \mathrm{wt} \% \mathrm{SiO}_{2}$ was therefore inferred to be the felsic end-member (Kametani et al. 2017; Takahashi et al. 2010). These observations indicate that mixing between hydrous basalt and dacite played a dominant role in the generation of intermediate magmas at Kusatsu-Shirane.

We studied the Sessho lava, which is an andesitic lava flow erupted from the Kagamiike pyroclastic cone at $5 \mathrm{ka}$ (Nigorikawa et al. 2016) with an estimated volume of $\sim 0.1 \mathrm{~km}^{3}$ (Hayakawa 1983). The lava is porphyritic, containing about 35 vol.\% plagioclase, opx, clinopyroxene (cpx), and magnetite phenocrysts, with rare olivine and rare quartz (Takahashi et al. 2010; Ueki and Terada 2012). The lava has an andesitic composition $\left(\mathrm{SiO}_{2}=60-63 \mathrm{wt} \%\right.$; Table 1; Takahashi et al. 2010; Uto et al. 1983).

\section{Analytical methods}

Samples were collected from different locations of the Sessho lava flow (Fig. 1). Back-scattered electron (BSE) images were collected and phenocryst compositions determined using a JEOL JXA-8800M electron probe micro-analyzer (EPMA) at the Department of Earth and Planetary Sciences, Tokyo Institute of Technology and at the Graduate School of Arts and Sciences of the University of Tokyo. The acceleration voltage was $15 \mathrm{kV}$ and the beam current $12 \mathrm{nA}$. Representative phenocryst compositions are given in Additional file 1. BSE images were also obtained by SEM-EDS (JEOL JSM-6010LA) at the School of Science and Engineering, Kokushikan University, with an accelerating voltage of $20 \mathrm{kV}$. Photomicrographs and BSE images are presented in Fig. 2 and Additional file 2.

Whole-rock major element concentrations were determined using an X-ray fluorescence spectrometer (XRF) at the Department of Earth and Planetary Sciences, Tokyo Institute of Technology (Rigaku Simultix 3550). For whole rock analyses, rock chips were sliced using a diamond saw to avoid surface contamination, polished on a grinder, rinsed in an ultrasonic bath, crushed manually in a tungsten pestle, and ground in an agate ball mill. The rock powder was dried at $110^{\circ} \mathrm{C}$ for more than $24 \mathrm{~h}$ before the preparation of fused glass beads. Fused glass beads were prepared from a mixture of $0.4 \mathrm{~g}$ of rock powder and $4.0 \mathrm{~g}$ of lithium tetraborate flux in a platinum melting pot (1:10 sample dilution). Details of the calibrations of the XRF analyses and analytical procedures used are given in Tani et al. (2002). A representative bulk composition is presented in Table 1. 

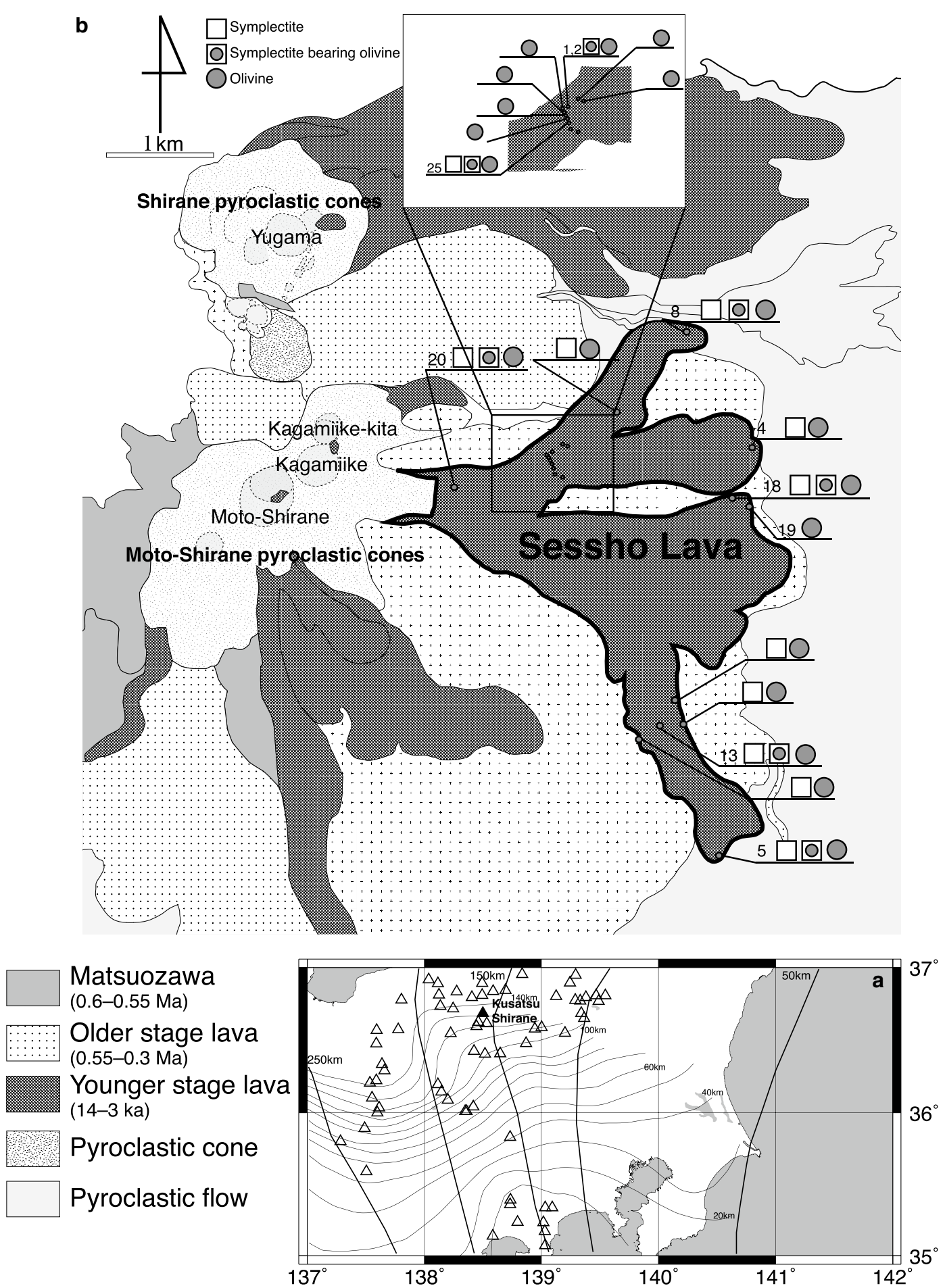

Fig. 1 a Location and simplified tectonic map of Kusatsu-Shirane Volcano, prepared using Generic Mapping Tools (Wessel and Smith 1998). The locations of Quaternary volcanoes (Committee for Catalogue of Quaternary volcanoes in Japan 1999) are shown as triangles. Solid gray and black lines are contours of the depth of the upper surface of the Pacific Plate at 50-km intervals (Nakajima and Hasegawa 2006) and of the Philippine Sea Plate at 10-km intervals (Hirose et al. 2008; Nakajima et al. 2009), respectively (modified after Ueki and Terada 2012). b Geologic map of Kusatsu-Shirane, showing sampling locations, modified by Ueki and Terada (2012) after Uto et al. (1983) and Hayakawa and Yui (1989). The spatial distributions of symplectites and olivine are also shown. The star indicates the location of the bulk sample presented in Table 1. Numbers refer to the samples shown in Figs. 2, 3, 4, 5 and additional files 
Table 1 Representative bulk composition of the Sessho lava

\begin{tabular}{|c|c|}
\hline Sample number & KS1115 \\
\hline $\mathrm{SiO}_{2}$ & 61.96 \\
\hline $\mathrm{TiO}_{2}$ & 0.64 \\
\hline $\mathrm{Al}_{2} \mathrm{O}_{3}$ & 16.18 \\
\hline $\mathrm{Fe}_{2} \mathrm{O}_{3}$ & 7.26 \\
\hline $\mathrm{MnO}$ & 0.13 \\
\hline $\mathrm{MgO}$ & 3.51 \\
\hline $\mathrm{CaO}$ & 6.38 \\
\hline $\mathrm{Na}_{2} \mathrm{O}$ & 2.75 \\
\hline $\mathrm{K}_{2} \mathrm{O}$ & 1.88 \\
\hline $\mathrm{P}_{2} \mathrm{O}_{5}$ & 0.14 \\
\hline Latitude & 36.63 \\
\hline Longitude & 138.56 \\
\hline
\end{tabular}

\section{Petrography and mineral chemistry}

Several types of symplectite consisting of opaque and transparent minerals are found in the Sessho lava. Figure $2 \mathrm{a}, \mathrm{b}$ shows a symplectite core surrounded by finegrained opx. Figure 3 shows EPMA analyses of the lamellar zone of this symplectite. The EPMA analyses shown in Fig. 3 were randomly made across the lamellar zone of the symplectite. Therefore, the analytical results in Fig. 3 are considered to represent the variations in compositions due to variations in the ratios of the two phases present. We infer, therefore, that each end-member of this compositional variation represents the composition of a single phase, and the average of all the analyses is considered to represent the bulk composition of the symplectite zone. Figure 3 demonstrates that the symplectite comprises two phases: an Fe-bearing Si-absent phase and a silicate phase with a molar $\mathrm{Si}:(\mathrm{Mg}+\mathrm{Fe})$ ratio of 1:1. These EPMA analyses indicate that the transparent silicate mineral in the symplectite is opx and the opaque mineral is magnetite. Opx in the symplectite and in the surrounding rim is fine-grained and exhibits low birefringence. Magnetite typically occurs in lamellae of $1-5 \mu \mathrm{m}$ in width.

Three types of olivine are identified: unrimmed olivine (Fig. 2c, d), olivine with a thin rim of opx and magnetite lamellae at the opx-olivine interface (opx-rimmed olivine; Fig. 2e, f), and olivine surrounded by a symplectite zone and a fine-grained opx rim (Fig. 2g, h). The spatial distribution of these various olivine and symplectite types is summarized in Fig. 1.

Olivine and opx zoning profiles are presented in Fig. 4. The EPNA analyses of the symplectite zone in Fig. 4 were carefully arranged to analyze a single opx phase. The analytical results were carefully scrutinized and any analyses that captured two phases (opx and magnetite) were discarded. The unrimmed olivine (Fig. 4a) has a homogeneous core with $\mathrm{Mg \#} \mathrm{(molar} \mathrm{MgO} /(\mathrm{MgO}+\mathrm{FeO}$ ) value $>80$ and normally zoned edges. The opx-rimmed olivine in Fig. 4b has a normally zoned core with $\mathrm{Mg} \#<80$ at its center. The olivine surrounded by zones of symplectite (Fig. 4c) has a homogeneous composition of $\mathrm{Mg \# <70.} \mathrm{Opx} \mathrm{in} \mathrm{a} \mathrm{symplectite} \mathrm{core} \mathrm{has} \mathrm{a} \mathrm{homogeneous}$ composition with a Mg\# value of $\sim 65$ (Fig. $4 \mathrm{~d}$ ). Opx rims associated with olivine or symplectite cores exhibit normal zoning (Fig. 4). The opx at the olivine-opx interface exhibits a higher Mg\# value than the coexisting olivine (Fig. 4).

The compositions of isolated opx and cpx phenocryst edges are shown in Fig. 5, together with the two-pyroxene isotherms of Lindsley (1983). The edges of opx phenocrysts typically have $\mathrm{Mg} \#$ values of 60-65, which correspond to the Mg\# values of the opx in the symplectite. Crystal pairs of opx with Mg\# values of 60-65 and adjacent cpx yield temperatures of $866-958{ }^{\circ} \mathrm{C}$ (average, $911{ }^{\circ} \mathrm{C}$ ) and pressures of 5-9 kbar (average, $7.3 \mathrm{kbar}$ ), as estimated using the two-pyroxene geothermobarometer of Putirka (2008). Some opx and cpx grains exhibit

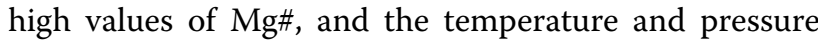
calculated for one pair of high-Mg\# opx and adjacent cpx $\left(1076{ }^{\circ} \mathrm{C}\right.$ and $2.8 \mathrm{kbar}$, respectively) indicate that the high-Mg\# pyroxene has a different origin to the low-Mg\# pyroxenes and symplectites.

\section{Symplectite formation mechanism}

The formation of opx-mt symplectites in igneous rocks has mostly been attributed to the breakdown of olivine (Ambler and Ashley 1977; Barton and van Gaans 1988; Barton et al. 1991; Del Moro et al. 2013; Fan et al. 2019; Goode 1974; Haggerty and Baker 1967; Johnston and Stout 1984; van Lamoen 1979; Moseley 1984). Petrological observations of the symplectites found in the Sessho lava (Figs. 2, 3, 4) demonstrate that they are associated with olivine. The major chemical constituents of the symplectites are Fe, Mg, and Si (Fig. 3 and Additional file 1). The stoichiometry of the average analyses in the symplectite zone corresponds to that of olivine (Fig. 3; mean $\mathrm{Si} /(\mathrm{Fe}+\mathrm{Mg})$ molar ratio $=0.5 \pm 0.3)$. Moreover, the symplectites have a concentric form, so that symplectites often surround an olivine core, and are always surrounded by a fine-grained opx rim. Magnetite lamellae between olivine and opx appear to be nearly perpendicular to the olivine-opx interface. These concentric fine-grained polyphase microstructures and the interface between the fine-grained and coarse-grained minerals are typical of symplectites that form after the breakdown of a mineral (Gaidies et al. 2017). We therefore conclude that the symplectites found in the Sessho lava are pseudomorphs after olivine. 

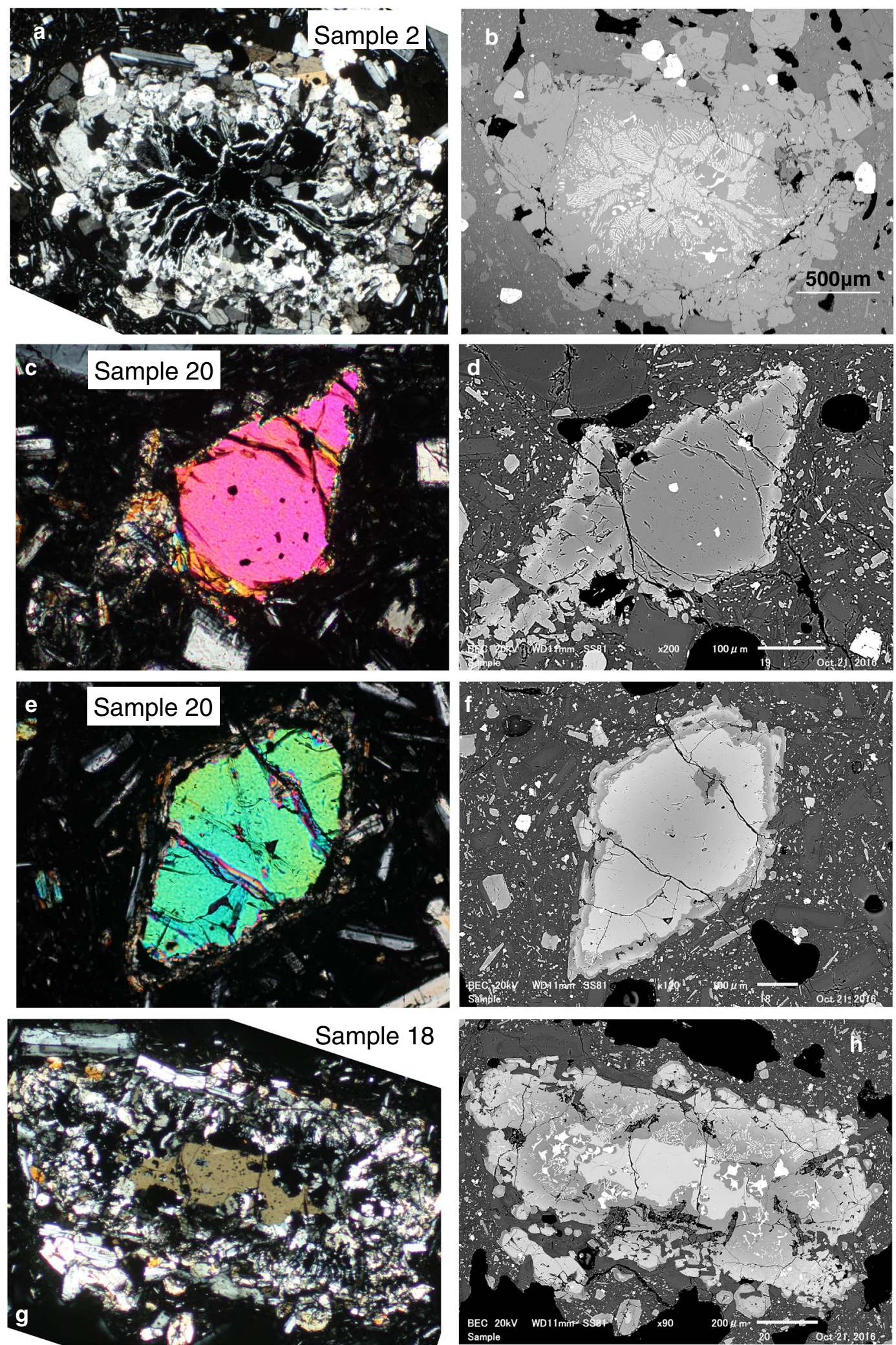

Fig. 2 Photomicrographs and BSE images of symplectites and olivine. $\mathbf{a}, \mathbf{b}$ Symplectite core surrounded by an opx rim. c, d Unrimmed olivine. e, $\mathbf{f}$ Opx-rimmed olivine. $\mathbf{g}, \mathbf{h}$ Symplectite with an olivine core and opx rim. 


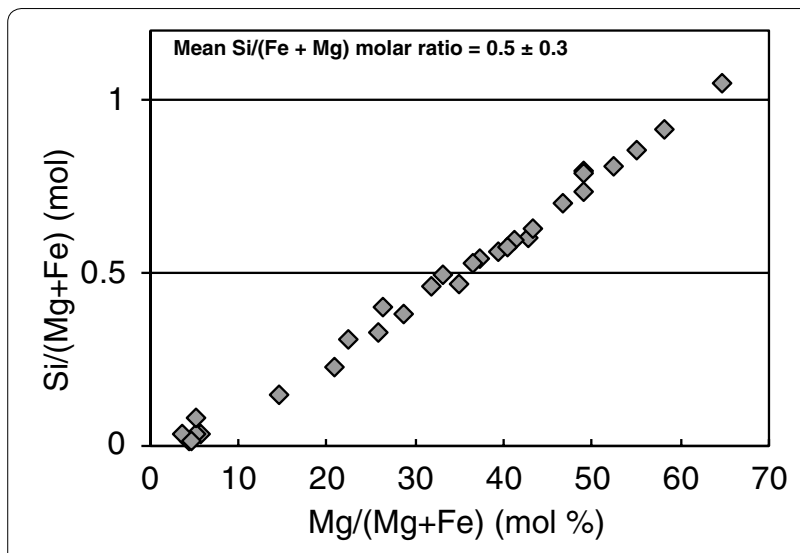

Fig. 3 EPMA analyses of a symplectite. EPMA analyses were randomly made across the lamellar zone of the symplectite shown in Fig. 2a, b

In the symplectites, opx has a Mg\# value that corresponds to that of the phenocryst edges, suggesting that the opx in the symplectite shown in Fig. 4 was formed at $911{ }^{\circ} \mathrm{C}$, above the solidus temperature of andesite (e.g., Green 1972; Huang and Wyllie 1986).

It has been suggested that opx-mt symplectites can be formed through the following oxidation reaction (e.g., Del Moro et al. 2013; Goode 1974; Haggerty and Baker 1967; Johnston and Stout 1984):

$$
\mathrm{Mg}_{2} \mathrm{SiO}_{4}+\mathrm{Fe}_{2} \mathrm{SiO}_{4}+1 / 3 \mathrm{O}_{2}=2 \mathrm{MgSiO}_{3}+2 / 3 \mathrm{Fe}_{3} \mathrm{O}_{4} .
$$

During this reaction, the bulk $\mathrm{Si}:\left(\mathrm{Fe}^{2+}+\mathrm{Fe}^{3+}+\mathrm{Mg}^{2+}\right)$ molar ratio of the system (1:2) is conserved, and the average stoichiometry of the lamellar zones of symplectites in the Sessho lava is 1:2 (Fig. 3). After oxidation, the opx that formed through the breakdown of olivine would exhibit higher values of $\mathrm{Mg} \#$ than the coexisting olivine, and there is an increase in Mg\# values at the opx-olivine interface in the symplectites (Fig. 4). We infer that the olivine-opx interface represents the oxidation reaction front.

Olivine and opx compositions (i.e., zoning profiles and $\mathrm{Mg \#}$ values) are systematically related to the types of symplectite and olivine (Fig. 4). These different types can be summarized consistently as snapshots of different stages of a continuous reaction-diffusion process. It is inferred that the more symplectized olivines record longer residence times. If we take the degree of symplectization to represent the residence time, the variations in the zoning profiles of olivine and opx can be interpreted to be the result of a continuous process of $\mathrm{Fe}-\mathrm{Mg}$ diffusion. Olivine crystals with no opx rim have flat cores with the highest Mg\#, and they are inferred therefore to have undergone the least $\mathrm{Fe}-\mathrm{Mg}$ diffusion (Fig. 4a). Olivines with an opx rim and magnetite lamellae exhibit normally zoned profiles, suggesting $\mathrm{Fe}-\mathrm{Mg}$ diffusion from the melt occurred (Fig. 4b). Olivines surrounded by a symplectite zone and opx rim have homogeneous cores with the lowest values of Mg\#, and they are inferred to have homogenized completely through $\mathrm{Fe}-\mathrm{Mg}$ diffusion (Fig. 4c). Similarly, it is inferred that the opx in Fig. $4 \mathrm{~b}$ records the least $\mathrm{Fe}-\mathrm{Mg}$ diffusion, the opx in Fig. 4c somewhat more $\mathrm{Fe}-\mathrm{Mg}$ diffusion, and the opx with the complete symplectite core that has the lowest Mg\# (Fig. 4d), the greatest amount of $\mathrm{Fe}-\mathrm{Mg}$ diffusion (Fig. 5). The widths of symplectite or lamellar zones (e.g., Fig. 2) correlate with the degree of $\mathrm{Fe}-\mathrm{Mg}$ diffusion in olivine and opx, which suggests that symplectite formation and $\mathrm{Fe}-\mathrm{Mg}$ diffusion proceeded simultaneously. The complete breakdown of olivine resulted in symplectites without olivine cores, and the opx in the rims and symplectites equilibrated with the melt.

Generally, a thin opx rim surrounding an individual olivine phenocryst indicates a reaction between the olivine and a non-equilibrium melt, suggesting magma mixing (e.g., Sakuyama 1979; Streck 2008). Based on Putirka (2005) which is a function of pressure, the $K_{D}^{\mathrm{Fe} / \mathrm{Mg}}(\mathrm{Fe}-$ $\mathrm{Mg}$ exchange coefficient between olivine and melt) at a crustal pressure of 1 bar to $1 \mathrm{GPa}$ is $0.29-0.32$. Based on the $K_{D}^{\mathrm{Fe} / \mathrm{Mg}}$ value, the $\mathrm{Mg} \#$ value of olivine in equilibrium with the bulk composition of the Sessho lava is 76.8-78.5 (Table 1), which indicates that the olivine without rims (Fig. 4a; maximum $\mathrm{Mg} \#=81$ ) did not crystallize from the host andesite. Hydrous basaltic melt inclusions in olivine from an andesitic lava at Kusatsu-Shirane (Yamaguchi et al. 2005) indicate that the olivine crystallized from a hydrous basalt. Based on the pressure and temperature estimates derived from amphiboles in melt inclusions within olivine, Yamaguchi et al. (2005) suggested that the olivine in the andesitic lava of Kusatsu-Shirane crystallized under lower-crustal conditions of $>950{ }^{\circ} \mathrm{C}$ and $>1$ $\mathrm{GPa}$, which point to greater depths than those indicated by the pressures and temperatures calculated using the pyroxene geothermobarometry $\left(911^{\circ} \mathrm{C}\right.$ and $7.3 \mathrm{kbar}$ on average). We infer, therefore, that the olivine-bearing basalt magma ascended from a lower-crustal magma reservoir and mixed with material in a middle-crustal magma reservoir to form the andesitic magma.

Mixing between olivine-bearing basalt magma and felsic magma results in the rapid formation of opx reaction rims around disequilibrium olivine (e.g., Coombs and Gardner 2004). However, a redox difference between the two magmas is necessary to produce opx-mt symplectites from olivine (Eq. 1). Thermodynamic calculations (Dohmen and Chakraborty 2007; Nitsan 1974) indicate that an increase in $f \mathrm{O}_{2}$ of $3 \mathrm{log}$ units from the NNO or QFM buffers can account for the breakdown of olivine 

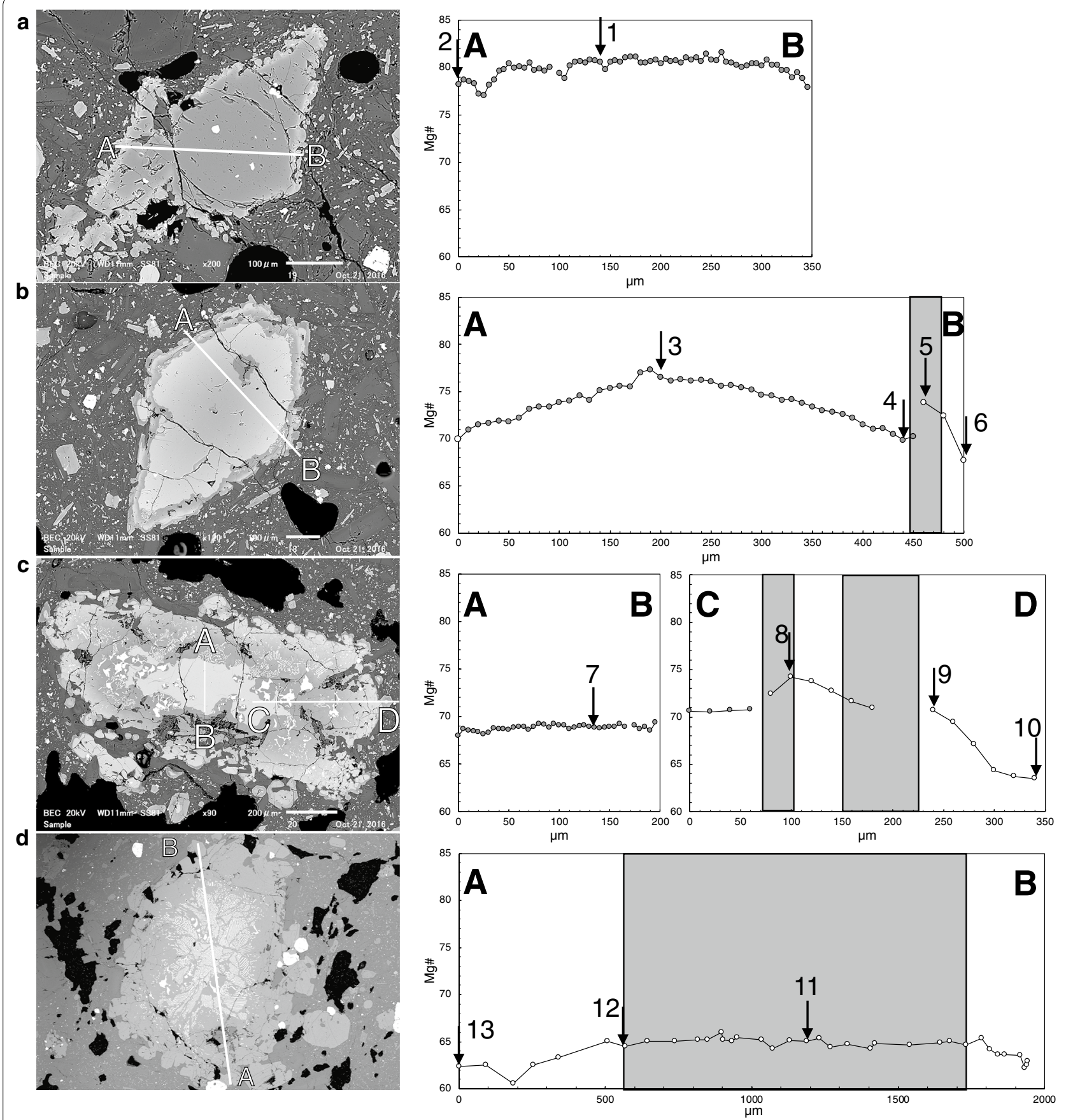

Fig. 4 Zoning profiles of olivine and opx in the examples shown in Fig. 2. Gray and white circles are olivine and opx analyses, respectively. The shaded areas represent symplectite or lamellar zones. Numbered arrows indicate locations of analyses given in Additional file 1

to form opx-mt symplectites. An $f \mathrm{O}_{2}$ contrast of similar magnitude is generally observed between mafic and felsic magmas (e.g., Carmichael 1991). Hence, we infer that the opx-mt symplectites were formed by oxidation during mixing between an oxidized felsic magma and a reduced mafic magma. As mentioned above, an $f_{2}$ contrast would be required to drive the reaction described by Eq. 1. Such an $f \mathrm{O}_{2}$ contrast would not be conserved when thermodynamic equilibrium is attained after the mixing of magmas with different temperatures and $f \mathrm{O}_{2}$ (Russell 1990). The interface between the high- $f \mathrm{O}_{2}$ felsic magma and low- $\mathrm{fO}_{2}$ mafic magma might be the site of such a 


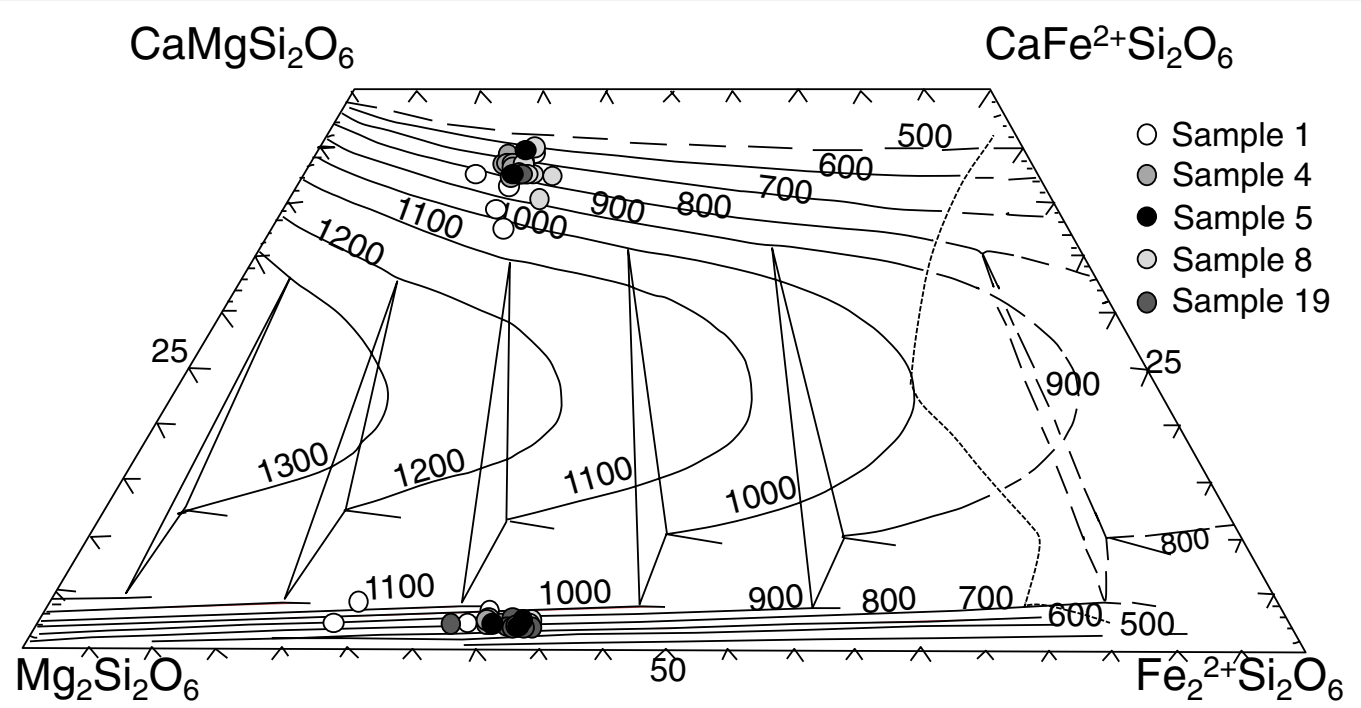

Fig. 5 Pyroxene phenocryst edge compositions obtained by EPMA analyses plotted on a pyroxene quadrilateral diagram with the 5-kbar isotherms of Lindsley (1983). The edges of isolated pyroxene phenocrysts were analyzed

contrast in $f \mathrm{O}_{2}$. The experimental results of Fiege et al. (2017) show that a redox gradient is rapidly developed through diffusion at the interface between felsic and mafic magmas.

Based on the diffusion and reaction sequence shown in Fig. 4, the reactions that account for the formation of the symplectites can be summarized as follows. The opx reaction rims around the olivine crystals (Fig. 2e, f) were formed by the reaction between olivine and felsic melt during magma mixing. The opx-mt symplectites were formed by a reaction driven by oxidation (Eq. 1). In some cases the reaction proceeded to completion, and the olivine crystal was completely replaced by symplectite (Fig. 2a, b). At the same time, Fe-Mg diffusion in olivine and opx proceeded, and both were homogenized (Fig. 4). Olivines and symplectites at various reaction stages coexist in a single lava flow (Fig. 1), indicating a range of residence times for the olivine crystals in the middle-crustal reservoir that fed the Sessho lava.

Although we assume that the symplectites formed through an oxidation reaction (Eq. 1) in which the bulk $\mathrm{Si}:(\mathrm{Fe}+\mathrm{Mg}$ ) ratio was conserved (Fig. 3), the process of formation may not have been in an entirely closed system. A gain of Fe from, and a loss of $\mathrm{Mg}$ to, the melt is necessary to produce the observed diffusion profiles (Fig. 4). $\mathrm{CaO}$ and $\mathrm{Al}_{2} \mathrm{O}_{3}$ contents in the opx in the symplectites are similar to those in the opx phenocrysts (Additional file 1). The simple oxidation of olivine (i.e., open to oxygen and closed to cations) and $\mathrm{Fe}-\mathrm{Mg}$ diffusion cannot explain the chemical imbalance. Consequently, a reaction in an open system is required to produce the observed chemical compositions of the symplectites. Ambler and Ashley (1977) proposed an open-system reaction in which symplectites are formed through the breakdown of olivine and the instantaneous precipitation of opx and magnetite from the surrounding melt.

\section{Geological implications}

The symplectites we studied were found in an andesitic lava flow and are assumed to have formed above the solidus, whereas most of the opx-mt symplectites described in previous studies were found in mafic-ultramafic plutonic rocks (Ambler and Ashley 1977; Barton and van Gaans 1988; Barton et al. 1991; Chambers and Brown 1995; Daval 1987; Johnston and Stout 1984) and were interpreted to have formed through a subsolidus reaction (Del Moro et al. 2013; Goode 1974; Haggerty and Baker 1967; Johnston and Stout 1984). This suggests that specific magma chamber conditions were required to form opx-mt symplectites from olivine above the solidus. Previous studies have showed that degassing can oxidize residual magmas (e.g., Candela 1986; Holloway 2004; Humphreys et al. 2015; Mathez 1984). These previous studies suggest the following redox reaction of $\mathrm{H}_{2} \mathrm{O}$ with ferrous iron in the melt:

$$
\mathrm{H}_{2} \mathrm{O} \text { (melt) }+2 \mathrm{FeO} \text { (melt) }=\mathrm{Fe}_{2} \mathrm{O}_{3} \text { (melt) }+\mathrm{H}_{2} \text { (gas) }
$$

and the subsequent degassing of $\mathrm{H}_{2}$ to oxidize the residual magma.

The typical eruptive style of Kusatsu-Shirane is effusive that produced lava flows and pyroclastic cones 
rather than the pyroclastic flows or widespread tephra deposits that result from explosive eruptions (e.g., Hayakawa and Yui 1989). An effusive eruptive style is indicative of efficient open-system outgassing from the magmatic system and a slow rate of magma ascent (Cassidy et al. 2018). Energy released by non-eruptive heat discharge (e.g., Kagiyama 1986, 2008) through hydrothermal activity is also prominent at KusatsuShirane. These geological and volcanological observations indicate efficient degassing from the magma reservoir beneath Kusatsu-Shirane, and we infer, therefore, that the magma was effectively oxidized by this degassing as $\mathrm{H}_{2}$ and related gas species were removed from the Kusatsu-Shirane magmas (e.g., Ohba et al. 2019; Ossaka et al. 1980).

The range of olivine and symplectite types indicates multiple injections of olivine-bearing basalt into the magma reservoir beneath Kusatsu-Shirane. In the Sessho lava, different olivine crystals and pseudomorphs after olivine coexist in a single flow, and even in a single sample (Fig. 1), showing that olivine crystals with different magma residence times coexisted in a single magma batch. Given that diffusivity has a unit of $\mathrm{m}^{2} / \mathrm{s}$, if one knows the diameter of the mineral and the diffusion coefficient, a timescale for $\mathrm{Fe}-\mathrm{Mg}$ diffusive reequilibration can be calculated as $\sim L^{2} / D$, where $L$ is the diameter of the mineral and $D$ is the diffusion coefficient (e.g., Zhang 2010). Based on the equation of Dohmen and Chakraborty (2007), which is a function of pressure, temperature, and olivine composition, the $\mathrm{Fe}-\mathrm{Mg}$ diffusion coefficient of olivine (Fig. 2c) is $10^{-17.7}\left(\mathrm{~m}^{2} / \mathrm{s}\right)$ at the average pressure and temperature determined in the present study $\left(7.3 \mathrm{kbar}\right.$ and $\left.911{ }^{\circ} \mathrm{C}\right)$. Based on this diffusion coefficient, the time required for $\mathrm{Fe}-\mathrm{Mg}$ diffusive re-equilibration of the unrimmed olivine (Fig. 2c) is estimated to be 509 years. Therefore, the typical time required for the formation of the symplectites and olivine zoning profiles is estimated to be $\sim 500$ years. Kusatsu-Shirane has had at least $\sim 10$ magmatic eruptions over the last 14 ky (Hayakawa and Yui 1989; Nigorikawa et al. 2016). The magmas from each eruption had slightly different compositions (Nigorikawa et al. 2016; Takahashi et al. 2010), and this variation is interpreted to have resulted from mixing between different basaltic andesites and a dacite (Takahashi et al. 2010). Olivine-bearing mafic magma was injected into the magma chamber repeatedly (every 500 years) and the olivines reacted with the oxidized felsic magma to form various types of olivine and symplectite. Eruptions of the hybrid andesite occurred, producing lava flows and pyroclastic cones. In other words, there is a steady-state magma chamber in which the influx of mafic magma and the outflux of evolved magma are balanced (de Silva et al. 2015).

\section{Concluding remarks}

We investigated the formation of opx-mt symplectites in the Sessho lava flow at Kusatsu-Shirane Volcano using detailed petrological observations. We conclude that the opx-mt symplectites were formed through the breakdown of olivine by oxidation caused by magma mixing. The different olivine and symplectite types were produced by multiple injections of olivine-bearing basalt into the magma reservoir beneath Kusatsu-Shirane. The following four processes were involved in the formation of the symplectites: (1) reaction between olivine and melt to form an opx reaction rim; (2) olivine oxidation and the exsolution of opx and magnetite to form symplectites; (3) $\mathrm{Fe}-\mathrm{Mg}$ diffusion in olivine and opx, and (4) the input of major elements $(\mathrm{Fe}, \mathrm{Ca}$, and $\mathrm{Al})$ from the melt. Some of these processes could have occurred simultaneously, such as the breakdown of olivine and the precipitation of opx and magnetite from the interstitial liquid (Ambler and Ashley 1977). The typical time required for the formation of the opx-mt symplectite after olivine is estimated to be $\sim 500$ years. Future study of the details of the symplectite-forming reaction-diffusion system, taking account of multiple phases (e.g., Ashworth and Chambers 2000; Gaidies et al. 2017; Nakamura 1995; Nishiyama 1983), will enable us to make better quantitative estimates on the time required for symplectite formation and to advance our understanding of the associated magmatic processes, including how the physicochemical conditions in the magma storage system beneath Kusatsu-Shirane Volcano produce symplectite-bearing andesitic magma.

\section{Supplementary information}

Supplementary information accompanies this paper at https://doi. org/10.1186/s40623-020-01192-4.

Additional file 1. Excel Spreadsheet with representative EPMA results (Figs. 4 and 5).

Additional file 2. BSE images of symplectites. Sample locations are given in Fig. 1.

\section{Abbreviations}

BSE: Back-scattered electron; cpx: Clinopyroxene; EPMA: Electron probe microanalyzer; $\mathrm{fO}_{2}$ : Oxygen fugacity; $\mathrm{Mg} \#$ : Molar $\mathrm{MgO} /(\mathrm{MgO}+\mathrm{FeO}$ ) value (\%); mt: Magnetite; opx: Orthopyroxene; SEM-EDS: Scanning electron microscopeenergy dispersive X-ray spectroscopy; XRF: X-ray fluorescence spectrometer.

\section{Acknowledgements}

We thank two anonymous reviewers for constructive reviews, and Yasuo Ogawa for editorial handling of the manuscript. We thank the Volcanic Fluid Research Center, School of Science, Tokyo Institute of Technology, for support in the field and fruitful discussions throughout this study. We received permission from Agatsuma District Forest Office, Ministry of Agriculture, Forestry and Fisheries for fieldwork and sampling. The authors also thank officials at Kusatsu Town, Gunma Prefecture, for assistance during fieldwork.

\section{Authors' contributions}

KU collected samples, performed XRF analyses, drafted the manuscript, and designed the framework of this study. MI collected samples, performed EPMA 
and SEM-EDS analyses, reviewed and edited the manuscript, and designed the framework of this study. NO, KM, and KO collected samples, performed EPMA and SEM-EDS analyses, and processed the data. All authors read and approved the final manuscript.

\section{Funding}

K.U. was supported financially by the Japan Society for the Promotion of Science KAKENHI Grant numbers JP17H02063 and JP19K04026.

\section{Availability of data and materials}

Representative analytical results are provided in Table 1 and Additional file 1. The data are available from the corresponding author (KU) upon request (kenta_ueki@jamstec.go.jp). Samples and thin sections are held in the laboratory of the second author (MI) at Kokushikan University.

\section{Ethics approval and consent to participate}

Not applicable.

\section{Consent for publication}

Not applicable.

\section{Competing interests}

The authors declare that they have no conflicts of interest.

\section{Author details}

${ }^{1}$ Research Institute for Marine Geodynamics, Japan Agency for MarineEarth Science and Technology, 2-15 Natsushima-cho, Yokosuka, Kanagawa 237-0061, Japan. ${ }^{2}$ School of Science and Engineering, Kokushikan University, 4-28-1, Setagaya, Setagaya-ku, Tokyo 154-8515, Japan.

Received: 11 February 2020 Accepted: 4 May 2020

Published online: 13 May 2020

\section{References}

Ambler EP, Ashley PM (1977) Vermicular orthopyroxene-magnetite symplectites from the Wateranga layered mafic intrusion, Queensland, Australia. Lithos 10:163-172. https://doi.org/10.1016/0024-4937(77)90044-5

Anderson AT (1976) Magma mixing: petrological process and volcanological tool. J Volcanol Geotherm Res 1:3-33. https://doi.org/10.1016/03770273(76)90016-0

Arndt NT (2013) The formation and evolution of the continental crust. Geochem Perspect 2:405

Ashworth JR, Chambers AD (2000) Symplectic reaction in olivine and the controls of intergrowth spacing in symplectites. J Petrol 41:285-304. https:// doi.org/10.1093/petrology/41.2.285

Barton M, van Gaans C (1988) Formation of orthopyroxene-Fe-Ti oxide symplectites in Precambrian intrusives, Rogaland, southwestern Norway. Am Mineral 73:1046-1059

Barton M, Sheets JM, Lee WE, van Gaans C (1991) Occurrence of low-Ca clinopyroxene and the role of deformation in the formation of pyroxeneFe-Ti oxide symplectites. Contrib Mineral Petrol 108:181-195. https://doi. org/10.1007/BF00307337

Candela PA (1986) The evolution of aqueous vapor from silicate melts: effect on oxygen fugacity. Geochim Cosmochim Acta 50:1205-1211. https:// doi.org/10.1016/0016-7037(86)90403-5

Carmichael ISE (1991) The redox states of basic and silicic magmas: a reflection of their source regions? Contrib Mineral Petrol 106:129-141. https://doi. org/10.1007/BF00306429

Cassidy M, Manga M, Cashman K, Bachmann O (2018) Controls on explosive-effusive volcanic eruption styles. Nat Commun 9:1-16. https://doi. org/10.1038/s41467-018-05293-3

Chambers AD, Brown PE (1995) The Lilloise intrusion, East Greenland: fractionation of a hydrous alkali picritic magma. J Petrol 36:933-963. https:// doi.org/10.1093/petrology/36.4.933

Committee for Catalog of Quaternary Volcanoes in Japan (1999) Catalog of Quaternary volcanoes in Japan, ver. 1.0 [CD-ROM]. The Volcanological Society of Japan, Tokyo
Coombs ML, Gardner JE (2004) Reaction rim growth on olivine in silicic melts: implications for magma mixing. Am Mineral 89:748-758. https://doi. org/10.2138/am-2004-5-608

Daval D (1987) Petrogenesis of orthopyroxene-magnetite-ilmenite intergrowths from an ultramafic layer. Contrib Mineral Petrol 95:301-310. https://doi.org/10.1007/BF00371844

De Silva SL, Riggs NR, Barth AP (2015) Quickening the pulse: fractal tempos in continental arc magmatism. Elements 11:113-118. https://doi. org/10.2113/gselements.11.2.113

Del Moro S, Renzulli A, Landi P, La Felice S, Rosi M (2013) Unusual lapilli tuff ejecta erupted at Stromboli during the 15 March 2007 explosion shed light on the nature and thermal state of rocks forming the crater system of the volcano. J Volcanol Geotherm Res 254:37-52. https://doi. org/10.1016/j.jvolgeores.2012.12.017

Dohmen R, Chakraborty S (2007) Fe-Mg diffusion in olivine II: point defect chemistry, change of diffusion mechanisms and a model for calculation of diffusion coefficients in natural olivine. Phys Chem Minerals 34:409-430. https://doi.org/10.1007/s00269-007-0158-6

Fan S, Zhang Z, Ma C, Xie Q, Wang L, Li Y, Zhang Y (2019) Coronas around olivine in the Miaowan olivine norite, Yangtze Craton, South China. J Earth Sci 30:924-937. https://doi.org/10.1007/s12583-019-1012-8

Fiege A, Ruprecht P, Simon A (2017) A magma mixing redox trap that moderates mass transfer of sulphur and metals. Geochem Perspect Lett 3:190-199. https://doi.org/10.7185/geochemlet.1722

Gaidies F, Milke R, Heinrich W, Abart R (2017) Metamorphic mineral reactions: porphyroblast, corona and symplectite growth. In: Heinrich W, Abart R (eds) Mineral reaction kinetics: microstructures, textures, chemical and isotopic signatures. EMU Notes in Mineralogy, vol. 16. Mineralogical Society of Great Britain and Ireland, London, pp. 469-540. https://doi. org/10.1180/emu-notes.16.14

Goode ADT (1974) Oxidation of natural olivines. Nature 248:500-501. https:// doi.org/10.1038/248500a0

Green TH (1972) Crystallization of calc-alkaline andesite under controlled highpressure hydrous conditions. Contrib Mineral Petrol 34:150-166. https:// doi.org/10.1007/BF00373770

Haggerty SE, Baker I (1967) The alteration of olivine in basaltic and associated lavas. Contrib Mineral Petrol 16:233-257. https://doi.org/10.1007/BF003 71094

Hayakawa Y (1983) Geology of Kusatsu-Shirane Volcano. J Geol Soc Jpn 89:511-525. https://doi.org/10.5575/geosoc.89.511 (in Japanese with English abstract)

Hayakawa Y, Yui M (1989) Eruptive history of the Kusatsu Shirane volcano. Quat Res 28:1-17. https://doi.org/10.4116/jaqua.28.1 (in Japanese with English abstract)

Hildreth W, Moorbath S (1988) Crustal contributions to arc magmatism in the Andes of central Chile. Contrib Mineral Petrol 98:455-489. https://doi. org/10.1007/BF00372365

Hirose F, Nakajima J, Hasegawa A (2008) Three-dimensional seismic velocity structure and configuration of the Philippine Sea slab in southwestern Japan estimated by double-difference tomography. J Geophys Res 113:B09315. https://doi.org/10.1029/2007JB005274

Holloway JR (2004) Redox reactions in seafloor basalts: possible insights into silicic hydrothermal systems. Chem Geol 210:225-230. https://doi. org/10.1016/j.chemgeo.2004.06.009

Huang WL, Wyllie PJ (1986) Phase relationships of gabbro-tonalite-granitewater at $15 \mathrm{kbar}$ with applications to differentiation and anatexis. Am Mineral 71:301-316

Humphreys MC, Brooker RA, Fraser DG, Burgisser A, Mangan MT, McCammon C (2015) Coupled interactions between volatile activity and Fe oxidation state during arc crustal processes. J Petrol 56:795-814. https://doi. org/10.1093/petrology/egv017

Johnston AD, Stout JH (1984) Development of orthopyroxene-Fe/Mg ferrite symplectites by continuous olivine oxidation. Contrib Mineral Petrol 88:196-202. https://doi.org/10.1007/BF00371423

Kagiyama T (1986) Thermal activity of volcano. Bull Volcanol Soc Jpn 30:S121S136. https://doi.org/10.18940/kazanc.30.TOKUBE_S121 (in Japanese with English abstract)

Kagiyama T (2008) Eruption dominant volcanism vs. geothermal activity dominant volcanism — new aspect in volcanism. J Geotherm Res Soc Jpn 30:193-204. https://doi.org/10.11367/grsj1979.30.193 (in Japanese with English abstract) 
Kametani N, Ishizaki Y, Yoshimoto M, Terada A (2017) Holocene eruption history of Kusatsu-Shirane volcano [in Japanese]. Paper presented at Volcanological Society of Japan 2017 Fall meeting, Kumamoto University, Kumamoto, Japan. 21 September 2017. https://doi.org/10.18940/ vsj.2017.0_204

Kaneko T, Shimizu S, Itaya T (1991) K-Ar ages of the Quaternary volcanoes in the Shin-etsu highland area, central Japan, and their formation history. Bull ERI Univ Tokyo 66:299-332 (in Japanese with English abstract)

Kashiwagi H, Nakajima J (2019) Three-dimensional seismic attenuation structure of central Japan and deep sources of arc magmatism. Geophys Res Lett. https://doi.org/10.1029/2019GL084793

Koyaguchi T (1986) Textural and compositional evidence for magma mixing and its mechanism, Abu volcano group, Southwestern Japan. Contrib Mineral Petrol 93:33-45. https://doi.org/10.1007/BF00963583

Kumagai H, Chouet BA, Nakano M (2002) Temporal evolution of a hydrothermal system in Kusatsu-Shirane Volcano, Japan, inferred from the complex frequencies of long-period events. J Geophys Res 107:2236. https://doi.org/10.1029/2001jb000653

Lindsley DH (1983) Pyroxene thermometry. Am Mineral 68:477-493

Mathez EA (1984) Influence of degassing on oxidation states of basaltic magmas. Nature 310:371-375. https://doi.org/10.1038/310371a0

Matsunaga Y, Kanda W, Takakura S, Koyama T, Saito Z, Seki K, Suzuki A, Kishita T, Kinoshita Y, Ogawa Y (2020) Magmatic hydrothermal system inferred from the resistivity structure of Kusatsu-Shirane Volcano. J Volcanol Geotherm Res 390:106742. https://doi.org/10.1016/j.jvolg eores.2019.106742

Moseley D (1984) Symplectic exsolution in olivine. Am Mineral 69:139-153

Nagai M, Ueki K, Mizuno Y, Tanaka Y, Inui M (2015) Stratigraphy and radiometric ages of volcanic rocks from the drill hole of the Hoshimata observation station of Kusatsu-Shiranesan Volcano, Central Japan [in Japanese]. Paper presented at Volcanological Society of Japan 2015 Fall meeting, University of Toyama, Toyama, Japan, 28-29 September 2015. https://doi.org/10.18940/vsj.2015.0 113

Nakajima J, Hasegawa A (2006) Anomalous low-velocity zone and linear alignment of seismicity along it in the subducted Pacific slab beneath Kanto, Japan: reactivation of subducted fracture zone? Geophys Res Lett 33:L16309. https://doi.org/10.1029/2006GL026773

Nakajima J, Tsuji Y, Hasegawa A (2009) Seismic evidence for thermally-controlled dehydration reaction in subducting oceanic crust. Geophys Res Lett 36:L03303. https://doi.org/10.1029/2008GL036865

Nakamura M (1995) Residence time and crystallization history of nickeliferous olivine phenocrysts from the northern Yatsugatake volcanoes, Central Japan: application of a growth and diffusion model in the system Mg-Fe-Ni. J Volcanol Geotherm Res 66:81-100. https://doi. org/10.1016/0377-0273(94)00054-K

Nakano M, Kumagai H (2005) Response of a hydrothermal system to magmatic heat inferred from temporal variations in the complex frequencies of long-period events at Kusatsu-Shirane Volcano, Japan. J Volcanol Geotherm Res 147:233-244. https://doi.org/10.1016/j.jvolg eores.2005.04.003

Nakano M, Kumagai H, Chouet BA (2003) Source mechanism of long-period events at Kusatsu-Shirane Volcano, Japan, inferred from waveform inversion of the effective excitation functions. J Volcanol Geotherm Res 122:149-164. https://doi.org/10.1016/S0377-0273(02)00499-7

Nigorikawa A, Ishizaki Y, Kametani N, Yoshimoto M, Terada A, Ueki K, Nakamura K (2016) Holocene eruption history of the Motoshirane pyroclastic cone group, Kusatsu-Shirane Volcano, Japan. Paper presented at Japan Geoscience Union Meeting 2016, Makuhari Messe, Chiba, Japan, 22 May 2016

Nishiyama T (1983) Steady diffusion model for olivine-plagioclase corona growth. Geochim Cosmochim Acta 47:283-294. https://doi. org/10.1016/0016-7037(83)90141-2

Nitsan U (1974) Stability field of olivine with respect to oxidation and reduction. J Geophys Res 79:706-711. https://doi.org/10.1029/JB079i005p 00706

Nurhasan, Ogawa Y, Ujihara N, Tank SB, Honkura Y, Onizawa S, Mori T, Makino M (2006) Two electrical conductors beneath Kusatsu-Shirane volcano, Japan, imaged by audiomagnetotellurics, and their implications for the hydrothermal system. Earth Planet Space 58:1053-1059. https://doi. org/10.1186/BF03352610
Ohba T, Hirabayashi Jl, Nogami K (2008) Temporal changes in the chemistry of lake water within Yugama Crater, Kusatsu-Shirane Volcano, Japan: implications for the evolution of the magmatic hydrothermal system. J Volcanol Geotherm Res 178:131-144. https://doi.org/10.1016/j.jvolg eores.2008.06.015

Ohba T, Yaguchi M, Nishino K, Numanami N, Tsunogai U, Ito M, Shingubara $R$ (2019) Time variation in the chemical and isotopic composition of fumarolic gasses at Kusatsu-Shirane Volcano, Japan. Front Earth Sci 7:249. https://doi.org/10.3389/feart.2019.00249

Ossaka J, Ozawa T, Nomara T, Ossaka T, Hirabayashi J, Takaesu A, Hayashi $T$ (1980) Variation of chemical compositions in volcanic gases and water at Kusatsu-Shirane Volcano and its activity in 1976. Bull Volcanol 43:207-216. https://doi.org/10.1007/BF02597622

Putirka KD (2005) Mantle potential temperatures at Hawaii, Iceland, and the mid-ocean ridge system, as inferred from olivine phenocrysts: evidence for thermally driven mantle plumes. Geochem Geophys Geosyst 6:8. https://doi.org/10.1029/2005gc000915

Putirka KD (2008) Thermometers and barometers for volcanic systems. Rev Mineral Geochem 69:61-120. https://doi.org/10.2138/rmg.2008.69.3

Russell JK (1990) Magma mixing processes; insights and constraints from thermodynamic calculations. Rev Mineral Geochem 24:153-190

Sakuyama M (1979) Evidence of magma mixing — petrological study of Shirouma-oike calc-alkaline andesite volcano, Japan. J Volcanol Geotherm Res 5:179-208. https://doi.org/10.1016/0377-0273(79)90040-4

Sparks SR, Sigurdsson H, Wilson L (1977) Magma mixing: a mechanism for triggering acid explosive eruptions. Nature 267:315-318. https://doi. org/10.1038/267315a0

Streck MJ (2008) Mineral textures and zoning as evidence for open system processes. Rev Mineral Geochem 69:595-622. https://doi.org/10.2138/ rmg.2008.69.15

Sumi K (1977) The relationship of the rates of convective heat discharge to the tectonic provinces in Japan. Bull Geol Surv Jpn 28:277-325 (in Japanese with English abstract)

Takahashi M, Kawamata H, Yasui M, Kanamaru T (2010) Whole-rock major element chemistry for eruptive products of Kusatsu-Shirane volcano, central Japan: summary of 306 analytical data. Proc Inst Nat Sci Nihon Univ 45:205-254 (in Japanese with English abstract)

Tani K, Orihashi Y, Nakata S (2002) Major and trace components of silicate rocks by X-ray fluorescence spectrometer using fused glass beads: evaluation of analytical precision of three, six, eleven times dilution fused glass beads methods. Tech Res Rep ERI Univ Tokyo 8:26-46 (in Japanese with English abstract)

Tatsumi Y, Suzuki T (2009) Tholeiitic vs calc-alkalic differentiation and evolution of arc crust: constraints from melting experiments on a basalt from the Izu-Bonin-Mariana Arc. J Petrol 50:1575-1603. https://doi. org/10.1093/petrology/egp044

Terada A (2018) Kusatsu-Shirane volcano as a site of phreatic eruptions. J Geol Soc Jpn 124:251-270. https://doi.org/10.5575/geosoc.2017.0060 (in Japanese with English abstract)

Terada A, Morita Y, Hashimoto T, Mori T, Ohba T, Yaguchi M, Kanda W (2018) Water sampling using a drone at Yugama crater lake, Kusatsu-Shirane volcano, Japan. Earth Planet Space 70:64. https://doi.org/10.1186/ s40623-018-0835-3

Ueki K, Iwamori H (2017) Geochemical differentiation processes for arc magma of the Sengan volcanic cluster, northeastern Japan, constrained from principal component analysis. Lithos 290:60-75. https:// doi.org/10.1016/j.lithos.2017.08.001

Ueki K, Terada A (2012) Field excursion guide to Kusatsu-Shirane Volcano. Bull Volcanol Soc Jpn 57:235-251. https://doi.org/10.18940/kazan .57.4_235 (in Japanese with English abstract)

Ushioda M (2015) Magma mingling of the Kagusa lava in the Kusatsu Shirane volcano: preliminary results from analyses of a boring core. Paper presented at Japan Geoscience Union Meeting 2015, Makuhari Messe, Chiba, Japan, 26 May 2015

Uto K, Hayakawa Y, Aramaki S, Ossaka J (1983) Geological map of KusatsuShirane Volcano. Geological Survey of Japan, Tsukuba (in Japanese with English abstract)

van Lamoen H (1979) Coronas in olivine gabbros and iron ores from Susimäki and Riuttamaa, Finland. Contrib Mineral Petrol 68:259-268. https://doi.org/10.1007/BF00371546 
Wessel P, Smith WHF (1998) New, improved version of Generic Mapping Tools released. EOS Trans 79:579. https://doi.org/10.1029/98EO00426 Yamaguchi Y, Yamaguchi T, Ohta Y (2005) Amphibole as a daughter phase of olivine-hosted melt inclusion from Asama and Kusatsu-Shirane volcanoes. Earth Sci 59:57-61. https://doi.org/10.15080/agcjchikyukagak u.59.1_57 (in Japanese with English abstract)

Zhang Y (2010) Diffusion in minerals and melts: theoretical background. Rev Mineral Geochem 72:5-59. https://doi.org/10.2138/rmg.2010.72.2
Zhao D, Horiuchi S, Hasegawa A (1992) Seismic velocity structure of the crust beneath the Japan Islands. Tectonophys 212:289-301. https://doi. org/10.1016/0040-1951(92)90296-।

\section{Publisher's Note}

Springer Nature remains neutral with regard to jurisdictional claims in published maps and institutional affiliations.
Submit your manuscript to a SpringerOpen ${ }^{\odot}$ journal and benefit from:

- Convenient online submission

- Rigorous peer review

- Open access: articles freely available online

- High visibility within the field

Retaining the copyright to your article

Submit your next manuscript at $\boldsymbol{\nabla}$ springeropen.com 